\title{
Influence of the abiotic characteristics of sediments on the macrobenthic community structure of the Minho estuary saltmarsh (Portugal)
}

\author{
Thais C. Picanço ${ }^{1}$, C. Marisa R. Almeida ${ }^{1}$, Carlos Antunes ${ }^{1,2,3}$ and Pedro A. Reis ${ }^{1, *}$ \\ ${ }^{1}$ CIIMAR/CIMAR-Centro Interdisciplinar de Investigação Marinha e Ambiental, Universidade do Porto, Rua \\ dos Bragas, 289, 4050-123 Porto, Portugal. \\ 2 Aquamuseu do Rio Minho-Parque do Castelinho, 4920-290 Vila Nova de Cerveira, Portugal. \\ ${ }^{3}$ Escola Superior Gallaecia-Largo das Oliveiras, 4920 Vila Nova de Cerveira, Portugal. \\ *Corresponding author: pedroareis@ ciimar.up.pt
}

Received: $23 / 10 / 2013$

Accepted: 05/02/2014

\begin{abstract}
Influence of abiotic characteristics of sediments on the macrobenthic community structure of Minho estuary saltmarsh (Portugal)

This work studied the spatial and seasonal variations of the macrobenthic community structure of the Minho estuary saltmarsh, which involved examining the relationships between the macrobenthic community and the abiotic characteristics of the surrounding sediments: texture, organic matter content and metal $(\mathrm{Cd}, \mathrm{Cr}, \mathrm{Cu}, \mathrm{Fe}, \mathrm{Ni}, \mathrm{Pb}$ and $\mathrm{Zn})$ concentrations. These abiotic characteristics showed significant $(p<0.05)$ spatial and seasonal variations that demonstrated the complex sedimentary dynamics of this saltmarsh. The macrobenthic community structure consisted of 37 taxa belonging to 5 phyla: Annelida (10 taxa), Mollusca (4 taxa), Arthropoda (21 taxa), Chordata (1 taxon) and Sipuncula (1 taxon). The mean annual abundance was $1530 \mathrm{ind} / \mathrm{m}^{2}$, and the most abundant species were Cyathura carinata, Scolelepis squamata and Hediste diversicolor. The macrobenthic community showed no standard spatial distribution throughout the saltmarsh, and species abundances showed high seasonal variations that were directly dependent on the natural environmental conditions of each season. Although the Minho estuary saltmarsh showed evidence of anthropogenic contamination by metals, the macrobenthic community was not significantly influenced by their presence, and the main structuring factor was the texture of the sediments.
\end{abstract}

Key words: Macrobenthic community, metal, saltmarsh, Minho river.

\section{RESUMEN}

Influencia de las características abióticas del sedimento en la estructura de la comunidad macrobentónica del estuario del Río Minho (Portugal)

Este trabajo ha estudiado las variaciones espaciales y estacionales de la estructura de la comunidad macrobentónica del estuario del río Miño, incluyendo el estudio de las relaciones entre la comunidad macrobentónica y las características abióticas de los sedimentos: textura, contenido de materia orgánica y concentraciones de metales $(\mathrm{Cd}, \mathrm{Cr}, \mathrm{Cu}, \mathrm{Fe}, \mathrm{Ni}, \mathrm{Pb}$ y $\mathrm{Zn}$ ). Estas características abióticas han mostrado variaciones espaciales y estacionales significativas ( $\mathrm{p}<0.05)$, demostrando las complejas dinámicas sedimentarias de este estuario. La estructura de la comunidad macrobentónica fue constituida por treinta y siete taxa de cinco phyla: Annelida (diez taxa), Mollusca (cuatro taxa), Arthropoda (veintiuna taxa), Chordata (un taxon) y Sipuncula (un taxon). La media de la abundancia anual fue de $1530 \mathrm{ind} / \mathrm{m}^{2}$ y las especies más abundantes fueron Cyathura carinata, Scolelepis squamata y Hediste diversicolor. La comunidad macrobentónica no mostró una distribución espacial estándar a lo largo del estuario y sus abundancias mostraron elevadas variaciones estacionales directamente dependientes de las condiciones ambientales de cada estación. A pesar de que el estuario del Miño mostró evidencias de contaminación de metales de origen antropogénico, la comunidad macrobentónica no se vio significativamente afectada y el mayor factor estructural fue la textura de los sedimentos.

Palabras clave: Comunidad macrobentónica, metales, estuario, río Miño. 


\section{INTRODUCTION}

The study of macrobenthic community structures and their dynamics has been an ecological priority, as benthic faunal activities affect and regulate the physicochemical and biological processes of estuarine systems (Day et al., 1989). The macrobenthic community structure is also considered to be a useful instrument in the elaboration of ecological quality studies and environmental diagnostics, as it can reflect with high precision the previous environmental conditions of the ecosystem (Warwick, 1986; Lana, 1994). This usefulness can be related to the presence of macrobenthic species near the bottom of ecosystems or in sediments, as well as their low mobility (Canfield et al., 1994; Weisberg et al., 1997; Clarke \& Gorley, 2001). The characterization of macrobenthic community structures should include the study of species abundances, diversity and evenness indices (Farinha \& Trindade, 1994; Alves, 1996 and 2000; Gamboa, 1999; Mucha et al., 2003). Then, multivariate analyses can indicate the spatial and seasonal variations of the community and the influence of sediment abiotic characteristics (e.g., texture, organic contents and pollutants such as metals) in its distribution throughout the ecosystem during different seasons (Farinha \& Trindade, 1994; Alves, 1996 and 2000; Gamboa, 1999; Mucha et al., 2003; Reis et al., 2009).

Estuarine saltmarsh areas are excellent nursery and protection regions, but they can also accumulate high contaminant concentrations in their sediments and plants (Teal, 1986; Vale et al., 1990; Reis et al., 2009). Consequently, estuarine community structures can be influenced by geological and anthropogenic gradients of contamination, particularly of metals (Pearson \& Rosenberg, 1978; Rakocinski et al., 1997). However, the geological contribution of metals complicates the identification of potential sources of contamination and makes the interpretation of their disturbing effects significantly more difficult (Weisberg et al., 1997; Gaston \& Nasci, 1998; Mucha et al., 2003; Reis et al., 2009). Furthermore, the challenge of detecting anthropogenic impacts in naturally stressed systems such as estuaries and saltmarshes using biological assessment methods and indices is considered as a Quality Paradox (Dauvin, 2007; Elliott \& Quintino, 2007).

The international section of the Minho River (including its saltmarsh area) was classified as a Natura 2000 location. The saltmarsh area is particularly important to avifauna, about which some scientific knowledge is available (Farinha \& Trindade, 1994; Alves, 1996 and 2000; Gamboa, 1999). However, the composition and distribution of the subtidal macrozoobenthic community present in the saltmarsh area of the Minho Estuary remain unknown. Previous work has shown the importance of sediments in saltmarsh areas as sinks for contaminants such as heavy metals, and coupled with the potential of the macrozoobenthic community to transfer this pollution to higher trophic levels, the conditions suggest that a biogeochemical study approach is appropriate (Reis et al., 2009 and Mil-Homens et al., 2013a, b). Such biogeochemical studies are very scarce in Portuguese estuaries, and none have been reported in the particular case of the single saltmarsh existing in the Minho estuary.

Thus, the major aims of this work were to study the Minho estuary saltmarsh over a one-year period, determining the patterns of the macrozoobenthic community composition in relation to (i) the influence of the abiotic characteristics of sediments (texture, organic contents and metal concentrations) and (ii) species abundance, biomass and diversity. These data may be used to evaluate the importance of this particular area of the estuary for conservation purposes.

\section{MATERIALS AND METHODS}

\section{Study Area}

The Minho estuary is located in the northwest (NW) region of Portugal and includes a variety of habitats with great environmental value, such as its saltmarsh areas (at the junction of the rivers Minho and Coura, near Caminha village) (Farinha \& Trindade, 1994; Alves, 1996 and 2000; Gamboa, 1999). Indeed, the Minho estuary saltmarsh was considered as a metal pristine area by 
Reis et al. (2009), although the increase of local industrial and tourism (fishing and cruising) activities has introduced anthropogenic sources of metals into this ecosystem. The river Minho is $300 \mathrm{~km}$ long, and the $70 \mathrm{~km}$ furthest downstream are considered to be a natural boundary between Portugal and Spain; the area is usually referred to as the international section (Sousa et al., 2008). The river flows westward from the north of Spain (Cantabrian Mountains) and discharges into the Atlantic Ocean with an average annual flow rate of $300 \mathrm{~m}^{3} / \mathrm{s}$ (Sousa et al., 2013). The total area of the Minho watershed is approx. $17100 \mathrm{~km}^{2}$, but only $23 \mathrm{~km}^{2}$ are estuarine area (Sousa et al., 2008). The Minho estuary is part of a Natura 2000 site, which includes the entire international section of the river (Sousa et al., 2008). Additionally, the Coura River extends over $10 \mathrm{~km}$ in length and reaches the Minho estuary saltmarsh $2 \mathrm{~km}$ before the estuary mouth, with an annual average flow rate of $10 \mathrm{~m}^{3} / \mathrm{s}$ (Sousa et al., 2013). We selected 10 sampling sites according to the salinity gradient during high tide and their spatial locations (interior and exterior area) in the saltmarsh (Fig. 1), from which sediments were collected for assessing the macrobenthic community structures (abundances, diversity and evenness). The mean distances between the sampling sites were $800 \mathrm{~m}$ along the river Coura (sites 1-4) and $230 \mathrm{~m}$ in the interior areas (sites 5-10), covering a total saltmarsh area of $1.04 \mathrm{~km}^{2}$. Samples were also collected at these sites to assess the abiotic characteristics of their waters (near bottom: temperature, dissolved oxygen and salinity) and sediments (texture, organic contents and metal concentrations).

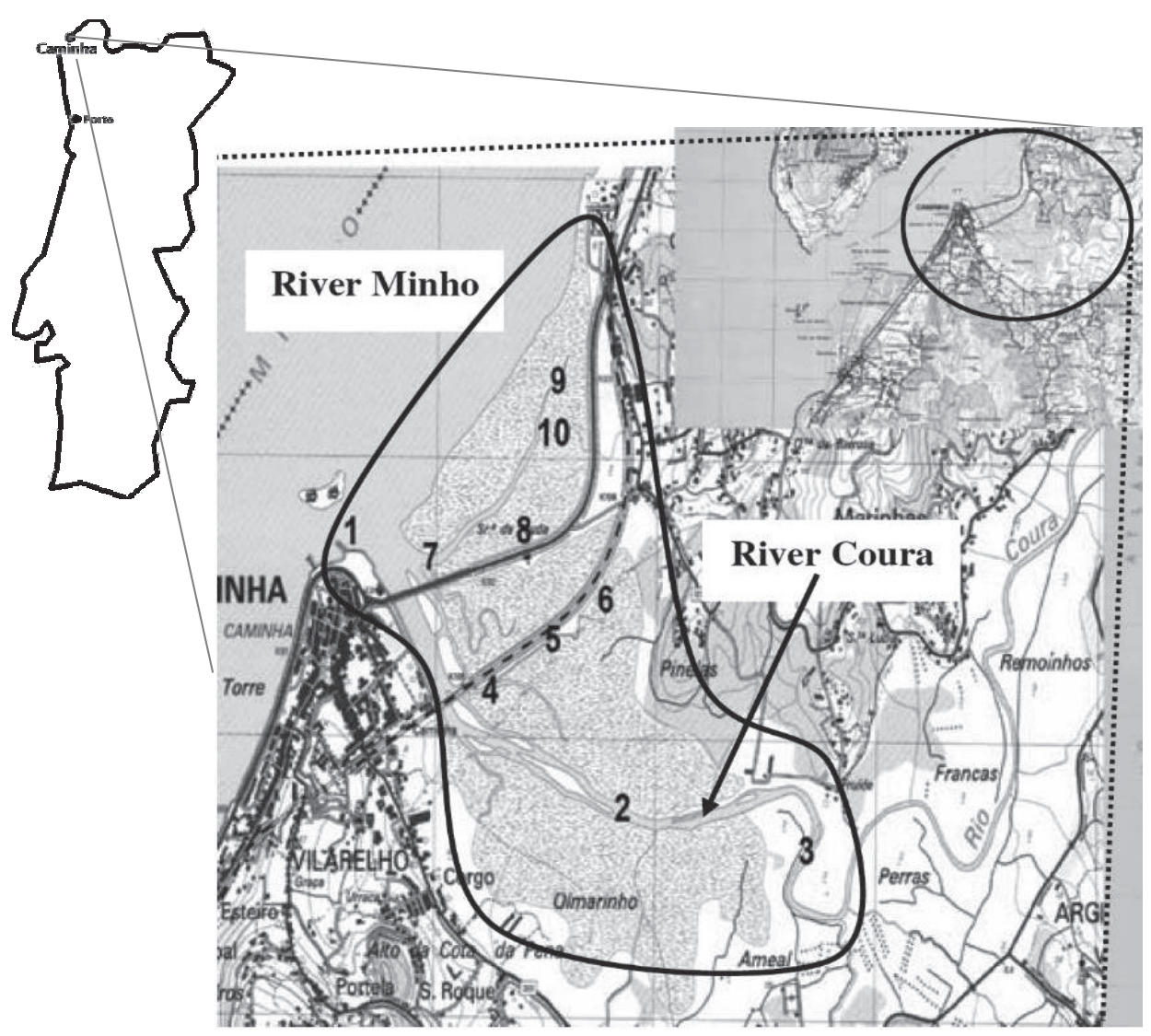

Figure 1. Locations of the 10 sampling sites in the Minho estuary saltmarsh (Portugal), near Caminha village (adapted from Reis et al., 2009). Localización de los diez puntos de muestreo en el estuario del río Miño (Portugal), cerca de la villa de Camiña (adaptado de Reis et al., 2009). 


\section{Reagents and materials}

The reagents and materials used in this study have been previously described by Reis et al. (2009): (i) the concentrated nitric acid (Fluka, pro analysis, without further purification) and the remaining reagents were of pro analysis level; (ii) ultrapure water (Milli-Q level, Millipore Systems) was used to prepare all solutions; (iii) Standard Reference Material certified for "Inorganics in Marine Sediment" (SRM 2702, NIST) was used to verify the suitability of the digestion procedure and of the optimized analytical method for the metal analyses in the sediments; and (iv) the material used in the sampling collections and treatments had been previously decontaminated in a $20 \%(\mathrm{v} / \mathrm{v})$ nitric acid solution.

\section{Sampling strategy and analytical methods}

Independent sediment replicates $(n=4)$ were collected using a Van Veen grab (area of $500 \mathrm{~cm}^{2}$ and a maximum capacity of $5000 \mathrm{~cm}^{3}$ ) at each site in September 2005 (summer), December 2005 (autumn) and March 2006 (winter) for abiotic and biotic characterization.

The analytical methods used to study the abiotic characteristics (texture, organic matter contents and metal concentrations) of the sediments have been previously described by Reis et al (2009). For texture characterization, the sediment samples were dried in an oven at $60^{\circ} \mathrm{C}$ for 48 hours, and dimensional analyses were conducted using a Ro-Tap sieves system. The weight of each class (gravel: $>2 \mathrm{~mm}$; very coarse sand: $1-2 \mathrm{~mm}$; coarse sand: $0.500-1 \mathrm{~mm}$; medium sand: $0.250-0.500 \mathrm{~mm}$; fine sand: $0.125-0.250 \mathrm{~mm}$; very fine sand: $<0.125 \mathrm{~mm}$; and clay and silts: $<0.063 \mathrm{~mm}$ ) was expressed as a percentage (\%) of total weight. The organic matter content was determined after combustion of the sediment samples in a furnace at $550^{\circ} \mathrm{C}$ for 24 hours, and the values were expressed as percentages (\%) relative to the initial sample weight. The metal $(\mathrm{Cd}, \mathrm{Cr}, \mathrm{Cu}$, $\mathrm{Fe}, \mathrm{Ni}, \mathrm{Pb}$ and $\mathrm{Zn}$ ) analyses have been described by Reis et al. (2009): digestion in Teflon vessels (model 4782, Parr) in a microwave system (model 440, Panasonic). The metal concentra- tions were determined by Atomic Absorption Spectrometry (SpectrAA 220 FS, Varian), coupled with a deuterium lamp as a background corrector, using flame atomization (Marck 7, Varian) and electrothermal atomization (GTA 110, Varian), depending on the metal concentrations in the samples (Reis et al., 2009). An adequate approach to study the potential anthropogenic contamination of sediments by metals is the normalization of these elements using a reference element not associated with contamination, such as Al, Li or Fe (Schiff \& Weisberg, 1999; Mucha et al., 2003; Reis et al., 2009). The study of Reis et al. (2009) used $\mathrm{Fe}$ as a conservative indicator for the following reasons: (i) $\mathrm{Fe}$ is the fourth-most-abundant metal on earth (with a mean concentration in superficial terrestrial sediments of $3.5 \%$ ); (ii) normally, anthropogenic sources of $\mathrm{Fe}$ are scarce compared with natural Fe concentrations; and (iii) the ratios between other metals and $\mathrm{Fe}$ are nearly constant in terrestrial sediments (Velinsky et al., 1994). Reis et al. (2009) showed that some interior areas of this saltmarsh had evidence of anthropogenic contamination by metals $(\mathrm{Cr}, \mathrm{Cu}, \mathrm{Ni}$ and $\mathrm{Pb})$.

For biotic characterization, the sediment samples were fixed with a buffered seawater-formalin solution $(10 \%, \mathrm{v} / \mathrm{v})$ and sieved through a $1 \mathrm{~mm}$ mesh for the separation of macrobenthic organisms. Then, the samples were preserved in an ethanol solution $(70 \%, \mathrm{v} / \mathrm{v})$ with Rose Bengal (as staining agent), and the organisms were counted and identified to the lowest possible taxon, normally the species level (Gaston \& Nasci, 1998).

\section{Data analyses}

Individual species abundance and biomass were expressed per square metre. Measures included abundance, biomass, number of species (S), Shannon-Wiener diversity index $\left(\mathrm{H}^{\prime}\right)$ and Pielou's evenness $\left(\mathrm{J}^{\prime}\right)$ index. Principal Component Analysis (PCA) was used to detect habitat differences based on the abiotic data and to establish correlations between biological parameters and abiotic characteristics; the indices of abiotic and biotic similarity were compared using BIO-ENV (using the Spearman coefficient) (Clarke \& War- 
wick, 1994). For statistical analyses of the biotic values, cluster multivariable analyses allowed for the study of the spatial and seasonal variations of species distributions (using SPSS software). For the statistical analyses of the abiotic values (or- ganic matter contents and metal concentrations in the sediments), the following sequence of steps was conducted: (i) the normality of the data was checked by the Shapiro-Wilk test, considering one level of significance $(p<0.05)$, using

Table 1. The physicochemical parameters of the waters, as well as the texture and organic matter contents of the sediments, of the Minho estuary saltmarsh obtained for the three sampling dates. Temperature $\left(\mathrm{T},{ }^{\circ} \mathrm{C}\right)$, dissolved oxygen $\left(\mathrm{DO}, \mathrm{mg} \cdot \mathrm{L}^{-1}\right)$, salinity $(\mathrm{S}, \mathrm{psu})$, gravel $(\mathrm{G}, \%)$, vary coarse sand (VCS, \%), coarse sand $(\mathrm{CS}, \%)$, medium sand (MS, \%), fine sand (FS, \%), very fine sand (VFS, \%), silt + clay (S+C, \%) and organic matter (OM, \%). Parámetros físico-químicos del agua, materia orgánica y textura de los sedimentos en el estuario del río Miño, obtenidos a lo largo de los tres muestreos. Temperatura $\left(T\right.$, $\left.{ }^{\circ} C\right)$, oxígeno disuelto $(D O$, $\left.m g \cdot L^{-1}\right)$, salinidad $(S, p s u)$, grava $(G, \%)$, arena muy gruesa $(V C S, \%)$, arena gruesa $(C S, \%)$, arena media $(M S, \%)$, arena fina $(F S$, $\%)$, arena muy fina $(V F S, \%)$, limo + arcilla $(S+C$, \%) y materia orgánica $(O M, \%)$.

\begin{tabular}{|c|c|c|c|c|c|c|c|c|c|c|}
\hline \multirow[b]{2}{*}{ Sampling Site } & \multicolumn{10}{|c|}{ Summer } \\
\hline & 1 & 2 & 3 & 4 & 5 & 6 & 7 & 8 & 9 & 10 \\
\hline $\mathbf{T}$ & 14.2 & 16.0 & 19.2 & 14.3 & 14.9 & 15.4 & 15.9 & 17.2 & 15.7 & 17.6 \\
\hline DO & 9.0 & 10.0 & 9.5 & 8.3 & 8.2 & 8.4 & 8.0 & 8.2 & 8.2 & 7.5 \\
\hline $\mathbf{S}$ & 34.4 & 29.4 & 16.9 & 33.5 & 33.4 & 32.0 & 31.0 & 29.0 & 31.0 & 24.7 \\
\hline $\mathbf{G}$ & 2.4 & 38.6 & 60.9 & 21.9 & 4.1 & 51.9 & 8.7 & 4.1 & 0.1 & 5.0 \\
\hline VCS & 7.8 & 35.5 & 22.2 & 29.4 & 9.9 & 16.7 & 10.3 & 8.2 & 0.5 & 8.0 \\
\hline CS & 34.4 & 20.7 & 13.7 & 23.9 & 24.3 & 15.9 & 27.1 & 26.3 & 9.7 & 8.5 \\
\hline MS & 20.6 & 4.1 & 2.5 & 21.5 & 19.6 & 12.9 & 39.7 & 35.8 & 27.1 & 29.9 \\
\hline FS & 19.3 & 0.7 & 0.4 & 2.2 & 11.5 & 0.9 & 6.3 & 13.9 & 23.6 & 10.3 \\
\hline VFS & 13.6 & 0.2 & 0.1 & 0.6 & 15.5 & 0.2 & 4.2 & 5.2 & 18.3 & 1.5 \\
\hline $\mathbf{S}+\mathbf{C}$ & 2.0 & 0.2 & 0.2 & 0.5 & 15.1 & 1.3 & 3.6 & 6.5 & 20.6 & 36.9 \\
\hline \multirow[t]{2}{*}{ OM } & 3.0 & 1.2 & 1.2 & 1.2 & 10.0 & 4.4 & 2.1 & 4.0 & 8.0 & 2.8 \\
\hline & \multicolumn{10}{|c|}{ Autumn } \\
\hline $\mathbf{T}$ & 13.4 & 9.9 & 10.7 & 12.1 & 9.0 & 8.7 & 13.0 & 11.6 & 9.1 & 8.7 \\
\hline DO & 7.0 & 11.0 & 9.9 & 11.1 & 10.8 & 9.8 & 9.5 & 7.0 & 7.6 & 7.4 \\
\hline $\mathbf{S}$ & 33.5 & 0.5 & 0.0 & 26.0 & 5.0 & 7.5 & 31.8 & 25.0 & 4.4 & 1.9 \\
\hline $\mathbf{G}$ & 8.1 & 77.0 & 3.6 & 38.7 & 11.6 & 5.9 & 16.6 & 4.6 & 0.8 & 0.9 \\
\hline VCS & 24.9 & 9.0 & 11.8 & 25.0 & 14.0 & 15.0 & 26.0 & 15.4 & 1.0 & 4.5 \\
\hline CS & 49.3 & 3.0 & 60.6 & 16.6 & 20.4 & 25.2 & 25.8 & 18.8 & 3.0 & 20.2 \\
\hline MS & 10.5 & 0.0 & 19.9 & 10.5 & 36.2 & 30.9 & 18.2 & 23.0 & 8.8 & 44.0 \\
\hline FS & 4.1 & 1.0 & 2.7 & 4.2 & 10.7 & 12.8 & 7.9 & 17.8 & 35.2 & 18.5 \\
\hline VFS & 2.3 & 5.0 & 1.0 & 2.2 & 3.5 & 6.2 & 3.8 & 7.5 & 35.0 & 6.8 \\
\hline $\mathrm{S}+\mathrm{C}$ & 0.8 & 5.0 & 0.4 & 2.8 & 3.7 & 4.1 & 1.6 & 13.0 & 16.2 & 4.9 \\
\hline \multirow[t]{2}{*}{ OM } & 1.7 & 1.4 & 1.3 & 2.7 & 3.3 & 6.9 & 1.9 & 5.2 & 11.2 & 8.2 \\
\hline & \multicolumn{10}{|c|}{ Winter } \\
\hline $\mathbf{T}$ & 13.2 & 12.3 & 12.0 & 11.7 & 12.8 & 12.9 & 13.1 & 12.5 & 11.7 & 12.4 \\
\hline DO & 9.1 & 10.8 & 10.8 & 11.0 & 10.9 & 11.0 & 9.0 & 9.6 & 11.5 & 11.1 \\
\hline $\mathbf{S}$ & 32.8 & 0.1 & 0.0 & 3.6 & 0.3 & 0.8 & 32.6 & 25.0 & 1.1 & 0.6 \\
\hline G & 70.3 & 81.8 & 9.9 & 38.3 & 1.6 & 9.7 & 15.1 & 7.0 & 0.2 & 4.9 \\
\hline VCS & 15.6 & 9.8 & 46.4 & 33.6 & 4.6 & 7.9 & 21.0 & 10.7 & 1.5 & 6.2 \\
\hline CS & 10.8 & 6.0 & 39.4 & 18.1 & 7.9 & 17.7 & 22.3 & 21.8 & 19.6 & 10.7 \\
\hline MS & 1.9 & 1.3 & 3.8 & 8.1 & 15.5 & 23.6 & 19.8 & 38.3 & 44.8 & 49.8 \\
\hline FS & 0.5 & 0.4 & 0.2 & 1.3 & 22.9 & 16.9 & 15.5 & 12.4 & 16.9 & 20.0 \\
\hline VFS & 0.5 & 0.3 & 0.2 & 0.3 & 29.6 & 13.0 & 4.6 & 4.7 & 9.4 & 4.8 \\
\hline $\mathbf{S}+\mathbf{C}$ & 0.4 & 0.4 & 0.2 & 0.3 & 18.0 & 11.3 & 1.6 & 5.1 & 7.5 & 3.6 \\
\hline OM & 1.3 & 1.5 & 1.1 & 1.2 & 11.3 & 11.0 & 1.5 & 3.8 & 5.1 & 2.2 \\
\hline
\end{tabular}


SPSS software; (ii) because some values failed the normality tests, all data were logarithmically (base 10) transformed to reduce deviations from the normal distribution; (iii) the homogeneity of variances was checked by the Cochran test, considering one level of significance $(p<0.05)$, using WinGMAv 5 software (EICC, University of Sydney); (iv) two-way analyses of variance (ANOVA) were used to identify significant spatial and seasonal differences $(p<0.05)$ using WinGMAv 5 software (EICC, University of Sydney); and (v) unplanned comparisons (post hoc tests) were conducted to establish groups of sampling sites and seasons which differed significantly ( $p<0.05$ ) using the Student-NewmanKeuls (SNK) test for ANOVAs from WinGMAv 5 software (EICC, University of Sydney).

\section{RESULTS AND DISCUSSION Environmental analyses}

Physicochemical parameters of waters and the texture and organic matter contents of sediments

The physicochemical parameters of the waters were directly influenced by the typical characteristics of each season and tide period: (i) higher temperatures and salinities during summer and at sampling sites more exposed to marine intrusion during high tide and (ii) lower temperatures and salinities during winter and at sites more exposed to fresh waters from the Coura River (Table 1). The dissolved oxygen concentrations were always higher than $7.0 \mathrm{mg} \cdot \mathrm{L}^{-1}$ for the three sampling dates, which indicated optimum concentrations ( $\mathrm{DO} \geq 6.0 \mathrm{mg} \cdot \mathrm{L}^{-1}$ at $15^{\circ} \mathrm{C}$ ) and well-mixed body waters (Reis et al., 2009). A number of sampling sites (i.e., sites 2-6 during winter) had saturated dissolved oxygen concentrations ( $\mathrm{DO} \geq$ $10.0 \mathrm{mg} \cdot \mathrm{L}^{-1}$ at $\left.15^{\circ} \mathrm{C}\right)$, suggesting excellent ecological qualities (Reis et al., 2009).

The textures of the sediments were constant across the saltmarsh during all seasons (except at site 7):

(i) gravel (>2 mm) and very coarse sand (1-2 $\mathrm{mm}$ ) fractions dominated at sites 1, 2, 3 and 4 (Coura River mainstream); (ii) very fine sand $(<0.125 \mathrm{~mm})$ and clay and silts $(<0.063 \mathrm{~mm})$ fractions dominated at site 5 (interior saltmarsh);

(iii) fine sand fraction $(0.125-0.250 \mathrm{~mm})$ dominated at sites $6,8,9$ and 10 (medium saltmarsh);

(iv) site 7 (interior saltmarsh) showed high seasonal variation, with the very fine sand, clay and silt fractions dominant during summer and the gravel and coarse sand fractions dominant during the autumn and winter. This result may be due to the higher rivers flows during autumn and winter, which could transport the finer sediments from this site to adjacent protected areas (sites 5-6 and 8-10).

These sediment textures were similar to those of other European estuaries: coarser sediments in the river areas (mainly in the Coura River: locations 1-4) and finer sediments in the protected interior areas (Diez, 1980; Mora, 1980; Asensio \& Gómez, 1984). Normally, these interior areas (locations 5-10) can retain finer sediments and have higher floral biomasses, which contribute to the formation of natural barriers that slow down water flows and accumulate high concentrations of metals (Diez, 1980; Mora, 1980; Asensio \& Gómez, 1984).

The saltmarsh areas with the finer sediments corresponded to the areas with the highest organic matter contents (Table 1). Normally, these areas also have a higher ability to retain contaminants in chemical forms that are more available to organisms, such as metals (Chapman \& Wang, 2001). As expected, organic matter contents were highest in the sediments of site 5, lowest at sites 1-4 and intermediate at sites 6 and 8-10 during all seasons. Only the sediments of site 7 suffered a high reduction of organic matter contents from summer to autumn and winter, which coincided with the change of texture.

\section{Heavy metal concentrations in sediments}

The metal ( $\mathrm{Cd}, \mathrm{Cr}, \mathrm{Cu}, \mathrm{Fe}, \mathrm{Ni}, \mathrm{Pb}$ and $\mathrm{Zn})$ concentrations in the sediments of the Minho estuary saltmarsh showed significant spatial and sea- 
sonal variations (Fig. 2 and Table 2). Detailed measurements of metal concentrations obtained in September 2005 (summer) can be found in Reis et al. (2009).

The limits of detection were calculated according to the APHA recommendations (Sediments (mg. $\mathrm{kg}^{-1}$, dry wt): Cd: 0.0041; Cr: 5.0; Cu: 0.046; Fe (\%): 0.25; Mn: 4.1; Pb: 0.099 and $\mathrm{Zn}$ : 9.1) (APHA, 1998; Reis et al., 2009). The analyses of the SRM 2702 showed acceptable mean recoveries for all of the metals: $\mathrm{Cd}(117.6 \%), \mathrm{Cr}$ (75.4\%), Cu (89.3\%), Fe (83.1\%), Pb (94.2\%) and $\mathrm{Zn}(92.5 \%)$, except for $\mathrm{Ni}(70.5 \%)$. Although the digestion procedure did not allow for the complete dissolution of the sediment sam- ples, digestion with only concentrated nitric acid is indicative of metal levels that are more environmentally bioavailable and have higher ecotoxicological potential (EPA, 1994).

The ANOVAs of the metal concentrations resulted in three significantly $(p<0.05)$ different clusters of sampling sites: (i) Group A with high metal concentrations, which included sites 5, 7 and 9; Group B with intermediate metal concentrations, which included sites 1, 6, 8 and 10; and Group $\mathrm{C}$ with low metal concentrations, which included sites 2, 3 and 4 (Fig. 2). These spatial distributions were directly influenced by the natural characteristics of the sediments of each sampling site at each season, as the sites with higher

Table 2. Two-way analyses of variance (ANOVAs) of metal $(\mathrm{Cd}, \mathrm{Cr}, \mathrm{Cu}, \mathrm{Fe}, \mathrm{Ni}, \mathrm{Pb}$ and $\mathrm{Zn}$ ) concentrations in the sediments of Minho estuary saltmarsh obtained for the three sampling dates, which allowed for the identification of significant spatial and seasonal differences $(p<0.05)$ using WinGMAv 5 software (EICC, University of Sydney). In each season, different letters shows significant spatial differences $(p<0.05)$ : increasing order of concentrations is $\mathrm{A}<\mathrm{B}<\mathrm{C}$, etc. In each location, different numbers shows significant temporal differences $(p<0.05)$ : increasing order of concentrations is $1<2<3$, etc. Análisis de varianza de dos vías (ANOVA) de las concentraciones de metales $(\mathrm{Cd}, \mathrm{Cr}, \mathrm{Cu}, \mathrm{Fe}, \mathrm{Ni}, \mathrm{Pb}$ y $\mathrm{Zn}$ ) de los sedimentos del estuario del río Miño, obtenidos a lo largo de los tres muestreos realizados, el cual ha permitido identificar diferencias espaciales y estacionales significativas ( $\mathrm{p}<0.05)$ : el orden de concentraciones crecientes es $A<B<C$, etc. En cada punto de muestreo, los diferentes números muestran diferencias temporales significativas ( $\mathrm{p}<0.05$ ): el orden de concentraciones crecientes es $1<2<3$, etc.

ANOVAS of metal concentrations in sediments of Minho estuary saltmarsh

\begin{tabular}{|c|c|c|c|c|c|c|c|c|c|c|c|}
\hline Metal & Sampling Season & 1 & 2 & 3 & 4 & 5 & 6 & 7 & 8 & 9 & 10 \\
\hline \multirow{3}{*}{ Cd } & Summer & $\mathrm{D}, \mathrm{E}, 2$ & $\mathrm{~A}, 1$ & $\mathrm{~B}, 1$ & $\mathrm{~B}, \mathrm{C}, 2$ & $\mathrm{~F}, 1$ & $\mathrm{E}, 1$ & $\mathrm{~F}, 2$ & $\mathrm{D}, \mathrm{E}, 2$ & $\mathrm{~F}, 2$ & $\mathrm{C}, \mathrm{D}, 1$ \\
\hline & Autumn & $\mathrm{B}, 2$ & $\mathrm{~B}, 3$ & $\mathrm{~B}, 1$ & $\mathrm{~B}, 2$ & $\mathrm{D}, 1$ & $\mathrm{C}, 1$ & $\mathrm{~A}, 1$ & $\mathrm{~B}, 1$ & $\mathrm{E}, 3$ & $\mathrm{~B}, \mathrm{C}, 1$ \\
\hline & Winter & $\mathrm{A}, \mathrm{B}, 1$ & $\mathrm{~A}, \mathrm{~B}, 2$ & $\mathrm{~B}, 1$ & $\mathrm{~A}, 1$ & $\mathrm{D}, 1$ & $\mathrm{C}, 1$ & $\mathrm{~B}, 1$ & $\mathrm{C}, 1,2$ & $\mathrm{C}, \mathrm{D}, 1$ & $\mathrm{C}, 1$ \\
\hline \multirow{3}{*}{$\mathrm{Cr}$} & Summer & $\mathrm{A}, \mathrm{B}, 1$ & $\mathrm{~A}, \mathrm{~B}, 1$ & $\mathrm{~A}, 1$ & $\mathrm{~A}, 1$ & $\mathrm{D}, 1$ & $\mathrm{~B}, \mathrm{C}, 1$ & $\mathrm{D}, 3$ & $\mathrm{D}, 3$ & $\mathrm{C}, \mathrm{D}, 1$ & $\mathrm{~B}, 1$ \\
\hline & Autumn & $\mathrm{A}, \mathrm{B}, 1$ & $\mathrm{~A}, \mathrm{~B}, 1$ & $\mathrm{~A}, 1$ & $\mathrm{~A}, \mathrm{~B}, 1$ & $\mathrm{C}, 1$ & $\mathrm{~A}, \mathrm{~B}, 1$ & $\mathrm{~A}, \mathrm{~B}, 1$ & $\mathrm{~A}, \mathrm{~B}, 1$ & $\mathrm{C}, 1$ & $\mathrm{~B}, \mathrm{C}, 1$ \\
\hline & Winter & $\mathrm{B}, 2$ & $\mathrm{~B}, 2$ & $\mathrm{~A}, 1$ & $\mathrm{~A}, 1$ & $\mathrm{D}, 2$ & $\mathrm{C}, 2$ & $\mathrm{C}, 2$ & $\mathrm{~B}, \mathrm{C}, 2$ & $\mathrm{~B}, \mathrm{C}, 1$ & $\mathrm{~B}, \mathrm{C}, 2$ \\
\hline \multirow{3}{*}{$\mathrm{Cu}$} & Summer & $\mathrm{B}, 2$ & $\mathrm{~B}, 1$ & $\mathrm{~B}, 1$ & $\mathrm{~A}, 1$ & $\mathrm{D}, 1$ & $\mathrm{C}, 1$ & $\mathrm{D}, 2$ & $\mathrm{C}, 1$ & $\mathrm{D}, 2$ & $\mathrm{~B}, 1$ \\
\hline & Autumn & $\mathrm{A}, 1$ & $\mathrm{D}, 2$ & $\mathrm{~B}, \mathrm{C}, \mathrm{D}, 1$ & $\mathrm{~A}, \mathrm{~B}, \mathrm{C}, 2$ & $\mathrm{E}, 1$ & $\mathrm{D}, 1$ & $\mathrm{~A}, \mathrm{~B}, 1$ & $\mathrm{C}, \mathrm{D}, 1$ & $\mathrm{~F}, 3$ & $\mathrm{D}, 2$ \\
\hline & Winter & $\mathrm{B}, \mathrm{C}, \mathrm{D}, 2$ & $\mathrm{~B}, \mathrm{C}, 1$ & $\mathrm{~B}, 1$ & A, 1 & $\mathrm{~F}, 2$ & $\mathrm{C}, \mathrm{D}, \mathrm{E}, 1$ & $\mathrm{D}, 1$ & $\mathrm{E}, 1$ & $\mathrm{E}, 1$ & $\mathrm{D}, \mathrm{E}, 2$ \\
\hline \multirow{3}{*}{$\mathbf{P b}$} & Summer & $\mathrm{A}, 1$ & $\mathrm{~A}, 1$ & $\mathrm{~A}, 1$ & $\mathrm{~A}, 1$ & $\mathrm{D}, 1$ & $\mathrm{~B}, 2$ & $\mathrm{C}, 2$ & $\mathrm{~B}, 2$ & $\mathrm{C}, 2$ & $\mathrm{~B}, 2$ \\
\hline & Autumn & $\mathrm{A}, 1$ & $\mathrm{~A}, 1,2$ & $\mathrm{~A}, 3$ & $\mathrm{~B}, 2$ & $\mathrm{D}, 1$ & $\mathrm{C}, 2$ & $\mathrm{~A}, 1$ & $\mathrm{~A}, 1$ & E,3 & $\mathrm{A}, 1$ \\
\hline & Winter & $\mathrm{D}, 2$ & $\mathrm{~B}, \mathrm{C}, \mathrm{D}, 2$ & $\mathrm{~B}, \mathrm{C}, \mathrm{D}, 2$ & $\mathrm{~A}, \mathrm{~B}, 1$ & $\mathrm{E}, 2$ & $\mathrm{~A}, 1$ & $\mathrm{~B}, \mathrm{C}, \mathrm{D}, 1$ & $\mathrm{C}, \mathrm{D}, 1,2$ & $\mathrm{~A}, \mathrm{~B}, \mathrm{C}, 1$ & $\mathrm{~A}, \mathrm{~B}, \mathrm{C}, 1$ \\
\hline \multirow{3}{*}{$\mathbf{N i}$} & Summer & $\mathrm{B}, 2$ & $\mathrm{~A}, 1$ & $\mathrm{~A}, 1$ & $\mathrm{~A}, 2$ & $\mathrm{E}, 1$ & $\mathrm{D}, 1$ & $\mathrm{~F}, 3$ & $\mathrm{D}, 1$ & $\mathrm{E}, 2$ & $\mathrm{~B}, \mathrm{C}, 1$ \\
\hline & Autumn & $\mathrm{A}, 1$ & $\mathrm{~A}, \mathrm{~B}, 1$ & $\mathrm{~A}, 1$ & $\mathrm{~A}, \mathrm{~B}, 2$ & $\mathrm{D}, 1$ & $\mathrm{C}, \mathrm{D}, 1$ & $\mathrm{~B}, 1$ & $\mathrm{C}, \mathrm{D}, 1$ & $\mathrm{E}, 2$ & $\mathrm{D}, 2$ \\
\hline & Winter & $\mathrm{B}, 2$ & $\mathrm{~B}, 2$ & $\mathrm{~A}, 1$ & $\mathrm{~A}, 1$ & $\mathrm{E}, 2$ & $\mathrm{C}, \mathrm{D}, 1$ & $\mathrm{C}, 2$ & $\mathrm{C}, \mathrm{D}, 1$ & $\mathrm{D}, 1$ & $\mathrm{C}, \mathrm{D}, 2$ \\
\hline \multirow{3}{*}{$\mathbf{Z n}$} & Summer & $\mathrm{A}, \mathrm{B}, \mathrm{C}, 1$ & $\mathrm{~A}, \mathrm{~B}, \mathrm{C}, 1$ & $\mathrm{~A}, \mathrm{~B}, 1$ & $\mathrm{~A}, 1$ & $\mathrm{E}, 1$ & $\mathrm{C}, \mathrm{D}, 1$ & $\mathrm{D}, \mathrm{E}, 2$ & $\mathrm{C}, \mathrm{D}, 1$ & $\mathrm{E}, 2$ & $\mathrm{~B}, 1$ \\
\hline & Autumn & $\mathrm{A}, 1$ & $\mathrm{~A}, \mathrm{~B}, 1$ & $\mathrm{~A}, \mathrm{~B}, 1$ & $\mathrm{~A}, 1$ & $\mathrm{C}, \mathrm{D}, 1$ & $\mathrm{~A}, \mathrm{~B}, 1$ & $\mathrm{~A}, \mathrm{~B}, 1$ & $\mathrm{~A}, \mathrm{~B}, 1$ & $\mathrm{D}, 2$ & $\mathrm{~B}, \mathrm{C}, 2$ \\
\hline & Winter & $\mathrm{B}, 1$ & $\mathrm{~B}, 1$ & $\mathrm{~B}, 1$ & $\mathrm{~A}, 1$ & $\mathrm{C}, 1$ & $\mathrm{~B}, 1$ & $\mathrm{~B}, 1$ & $\mathrm{~B}, 1$ & $\mathrm{~B}, 1$ & $\mathrm{~B}, 1$ \\
\hline \multirow{3}{*}{$\mathrm{Fe}$} & Summer & $\mathrm{A}, \mathrm{B}, 1,2$ & $\mathrm{~B}, \mathrm{C}, 1$ & $\mathrm{~A}, 1$ & $\mathrm{~A}, 1$ & $\mathrm{E}, 1$ & $\mathrm{D}, 1$ & $\mathrm{E}, 2$ & $\mathrm{~B}, \mathrm{C}, \mathrm{D}, 1$ & $\mathrm{~F}, 2$ & $\mathrm{C}, \mathrm{D}, 1$ \\
\hline & Autumn & $\mathrm{A}, 1$ & $\mathrm{~B}, 1$ & $\mathrm{~B}, 2$ & $\mathrm{~A}, 1$ & $\mathrm{D}, 1$ & $\mathrm{~B}, \mathrm{C}, 1$ & $\mathrm{~B}, 1$ & $\mathrm{~B}, 1$ & $\mathrm{E}, 3$ & $\mathrm{C}, 1$ \\
\hline & Winter & $\mathrm{B}, \mathrm{C}, 2$ & $\mathrm{~B}, \mathrm{C}, 1$ & $\mathrm{~B}, 1$ & $\mathrm{~A}, 1$ & $\mathrm{E}, 2$ & $\mathrm{D}, 1$ & $\mathrm{~B}, \mathrm{C}, 1$ & $\mathrm{~B}, \mathrm{C}, 1$ & $\mathrm{E}, 1$ & $\mathrm{C}, 1$ \\
\hline
\end{tabular}


metal concentrations had finer sediments and higher organic matter contents. This observation was corroborated by the seasonal variations of metal concentrations (Fig. 2 and Table 2: different numbers represent significant seasonal variations in each location), which also coincided with the variations of texture and organic matter contents between seasons. For example, the sediments of site 7 showed a great reduction of metal concentrations from summer to winter, which coincided with the reduction of their very fine sand, clay and silt fractions and organic matter contents.

The geological characteristics of the sediments complicate the distinction between natural and anthropogenic sources of organic and inorganic contaminants. An adequate approach to distinguish organic from inorganic contamination and natural from anthropogenic sources is the normalization of vestigial metals using a macroelement such as Al, Li or Fe (Mucha et al., 2003; Reis et al., 2009). Reis et al. (2009) already performed these normalizations in the sediments of the Minho estuary saltmarsh and revealed that sites 5 and 7 (interior saltmarsh areas) showed evidence of anthropogenic contamination by $\mathrm{Cr}, \mathrm{Cu}, \mathrm{Ni}$ and $\mathrm{Pb}$ during summer (minimum flows and metal dilution factors), but only site 5 continued to show that contamination during winter (maximum flows and metal dilution factors). These results suggest that the metal concentrations obtained in the sediments of the Minho estuary saltmarsh were not exclusively derived from natural sources, and these anthropogenic contributions might have also influenced the macrobenthic community structure of this saltmarsh. However, comparisons with other national wetlands have shown that the sediments of Minho estuary saltmarsh have much lower metal concentrations, being similar only to Ria Formosa (a summary table of metal concentrations in the superficial sediments of different Portuguese wetlands can be found in Reis et al. (2009).
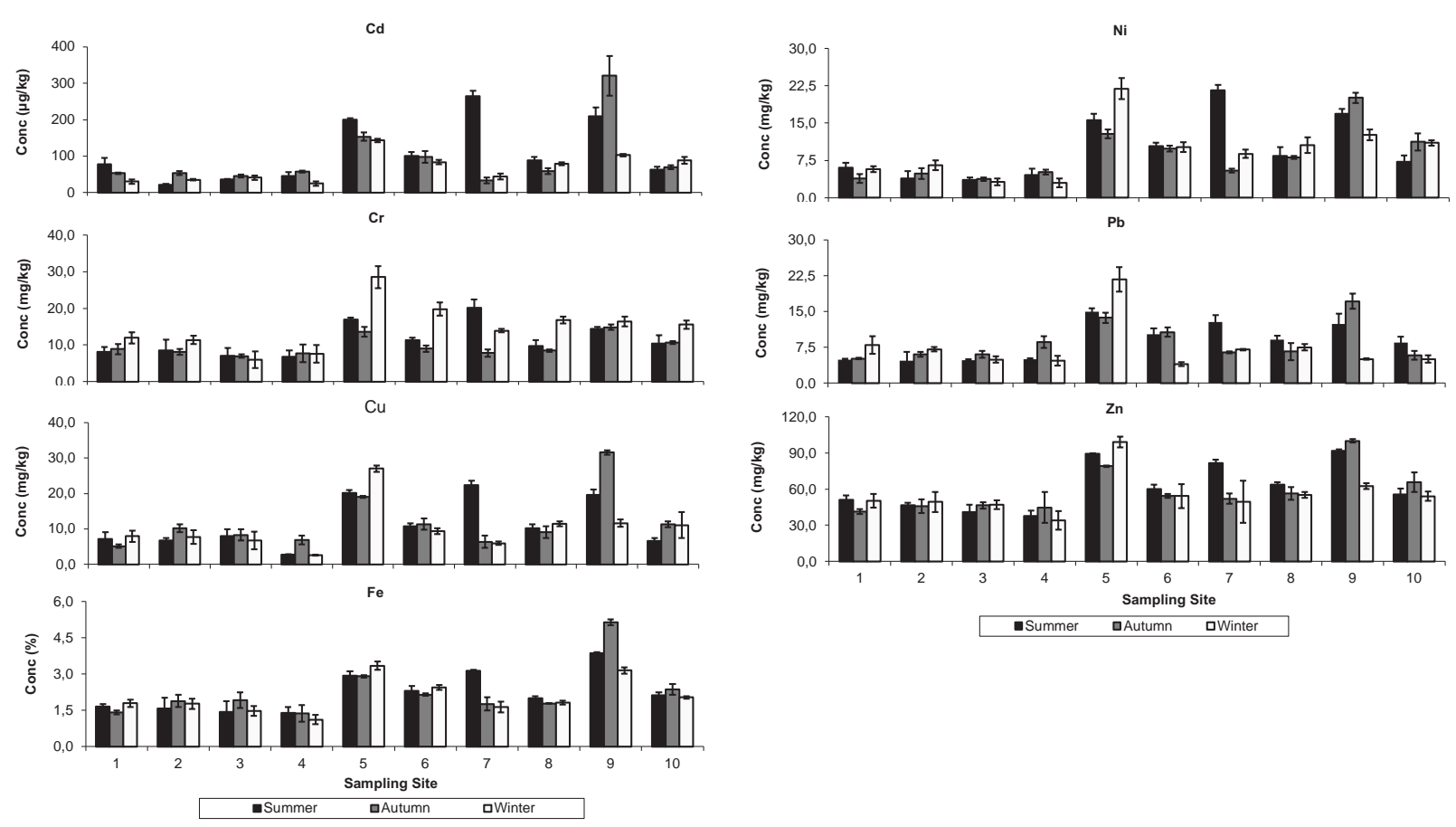

Figure 2. Metal concentrations ( $\mathrm{Cd}, \mathrm{Cr}, \mathrm{Cu}, \mathrm{Fe}, \mathrm{Ni}, \mathrm{Pb}$ and $\mathrm{Zn}$ ) of the sediments collected from each sampling site during each sampling trip. Concentración de metales $(\mathrm{Cd}, \mathrm{Cr}, \mathrm{Cu}, \mathrm{Fe}, \mathrm{Ni}, \mathrm{Pb}$ y $\mathrm{Zn}$ ) en los sedimentos recogidos en cada punto de muestreo, durante cada muestreo. 


\section{Biological analyses}

\section{Macrozoobenthos Abundance, Diversity and Evenness}

In the Minho estuary saltmarsh, a total of 10 185 individuals were identified during the three sampling dates, distributed across 5 phyla and 37 taxa: Annelida (10 taxa), Mollusca (4 taxa), Arthropoda (21 taxa), Chordata (1 taxon) and Sipuncula (1 taxon) (Appendix 1, available: www. limnetica.net/internet).

The mean annual abundance (per area unit) of the three sampling dates was $1530 \mathrm{ind} / \mathrm{m}^{2}$. The highest total abundance $\left(6330 \mathrm{ind} / \mathrm{m}^{2}\right.$ of nine different species) was observed at site 4 (Coura River mainstream) during summer (the peak of the macrobenthic recruitment season, with a total mean abundance of $1977.5 \mathrm{ind} / \mathrm{m}^{2}$ ). Site 4 presented sediments dominated by gravel and very coarse sand, low organic matter contents and minimum metal concentrations, which might represent an ideal uncontaminated area to macrobenthos. The lowest total abundance
(95.0 ind $/ \mathrm{m}^{2}$ of $3 \mathrm{different}$ species) was obtained at site 10 (intermediate saltmarsh) during winter (severe hydrodynamic conditions, with a total mean abundance of $744.0 \mathrm{ind} / \mathrm{m}^{2}$ ); this result can be directly related to the typical life cycle of the benthic species in the Minho estuary, which have their optimum recruitment periods during summer (Sousa et al., 2008). The sediments of site 10 were dominated by the fine sand fraction and had medium organic matter content, with no evidence of anthropogenic contamination by metals. Indeed, two sampling sites (4 and 10) considered to be uncontaminated by metals showed completely different total abundances. This result suggested that macrobenthic community structure was more dependent on the texture and organic matter contents typical of each season than on metal concentrations.

The species diversity of this saltmarsh showed no consistent pattern among the different sampling sites and seasons (Appendix 1, www.limnetica.net/internet and Table 3). However, the greatest number of different species of macrobenthos was observed in the Coura River mainstream

Table 3. Values of species number (S), Shannon-Wiener diversity index $\left(\log \mathrm{H}^{\prime}\right)$ and evenness index $\left(\mathrm{J}^{\prime}\right)$ of the Minho estuary saltmarsh obtained for the three sampling dates. Valores del número de especies ( $S$ ), indice de diversidad de Shannon-Weaver (log $H^{\prime}$ ) $e$ índice de homogeneidad $\left(J^{\prime}\right)$ del estuario del río Miño a lo largo de los tres muestreos.

\begin{tabular}{|c|c|c|c|c|c|c|c|c|c|c|}
\hline \multirow[b]{2}{*}{ Sampling Site } & \multicolumn{10}{|c|}{ Number of Species (S) } \\
\hline & 1 & 2 & 3 & 4 & 5 & 6 & 7 & 8 & 9 & 10 \\
\hline Summer & 13 & 10 & 14 & 9 & 13 & 11 & 9 & 8 & 6 & 10 \\
\hline Autumn & 10 & 13 & 17 & 11 & 11 & 7 & 9 & 8 & 6 & 5 \\
\hline \multirow[t]{2}{*}{ Winter } & 13 & 14 & 14 & 8 & 9 & 6 & 7 & 11 & 6 & 3 \\
\hline & \multicolumn{10}{|c|}{ Shannon-Weaver Diversity Index $\left(\log \mathbf{H}^{\prime}\right)$} \\
\hline Sampling Site & 1 & 2 & 3 & 4 & 5 & 6 & 7 & 8 & 9 & 10 \\
\hline Summer & 1.40 & 1.50 & 1.71 & 1.61 & 1.37 & 1.27 & 1.50 & 1.71 & 1.01 & 1.51 \\
\hline Autumn & 1.79 & 1.82 & 1.70 & 1.23 & 1.18 & 1.55 & 1.33 & 1.47 & 0.84 & 1.10 \\
\hline \multirow[t]{2}{*}{ Winter } & 1.25 & 1.25 & 1.94 & 1.11 & 1.52 & 1.48 & 1.34 & 1.87 & 0.79 & 0.91 \\
\hline & \multicolumn{10}{|c|}{ Evenness Index ( $\left.\mathbf{J}^{\prime}\right)$} \\
\hline Sampling Site & 1 & 2 & 3 & 4 & 5 & 6 & 7 & 8 & 9 & 10 \\
\hline Summer & 0.55 & 0.65 & 0.65 & 0.73 & 0.53 & 0.53 & 0.68 & 0.82 & 0.56 & 0.66 \\
\hline Autumn & 0.78 & 0.71 & 0.60 & 0.51 & 0.49 & 0.79 & 0.61 & 0.71 & 0.47 & 0.69 \\
\hline Winter & 0.49 & 0.47 & 0.74 & 0.53 & 0.69 & 0.83 & 0.69 & 0.78 & 0.44 & 0.83 \\
\hline
\end{tabular}


(sites 1-3) during all seasons, particularly at site 3, which had 17 different species during autumn. The remaining sites 5-10 showed only a few different species and had low Shannon-Wiener diversity indices, especially site 10, which had only 3 different species during winter. Once more, this result suggested that the texture and organic matter contents of the sediments were the main structuring factors of this macrobenthic community.

Although the species richness of the saltmarsh can be estimated by the number of species and the Shannon-Wiener diversity indices, the relative species abundance should be assessed by evenness indices (Table 3). These evenness indices $\left(0 \leq \mathrm{J}^{\prime} \leq 1\right)$ were at their maximum and minimum, respectively, in site $10\left(\mathrm{~J}^{\prime}=0.83\right)$ and site $9\left(\mathrm{~J}^{\prime}=0.44\right)$ during winter. Higher values of evenness indicate a more homogeneous community structure and less diversity. Thus, the higher evenness values of the interior saltmarsh areas (sites 6,8 and 10) indicated that these areas were less adapted to severe ecological changes. The remaining sites (1-5 and 7) showed intermediate

Table 4. Cluster Multivariable Analysis: mean similarity between groups, total abundance and dominant species per faunal group. The group $G_{1}$ was established without a mean similarity or species dominance. Numbers represent the sampling sites (1-10), and letters represent the sampling seasons (S-Summer; A-Autumn; W-Winter). BIO-ENV analysis of the abiotic factors (texture, organic matter contents and metal concentrations) of the sediments of the Minho estuary saltmarsh obtained for the three sampling dates. Análisis de agrupamiento multivariante: similaridad media entre grupos, abundancia total y especies dominantes por grupo faunístico. El grupo $G_{1}$ fue establecido en similitud media o especie dominante. Los números representan puntos de muestreo (1-10) y las letras representan épocas de muestreo (S-verano; A-otoño; W-invierno). Análisis BIOENV de los factores abióticos (textura, materia orgánica y concentraciones de metales) de los sedimentos del estuario del río Miño a lo largo de los tres muestreos.

\begin{tabular}{|c|c|c|c|c|c|c|}
\hline \multirow{2}{*}{$\begin{array}{l}\text { Faunistic } \\
\text { Group }\end{array}$} & \multicolumn{6}{|c|}{ CLUSTER ANALYSIS } \\
\hline & Site-Season & $\begin{array}{cc}\text { Mean Similarity } & \text { Tc } \\
(\%) & \end{array}$ & $\begin{array}{l}\text { Cotal Abundance } \\
(\%)\end{array}$ & Species Dominance & $\begin{array}{c}\text { Contribution } \\
(\%)\end{array}$ & $\begin{array}{c}\text { Total Contribution } \\
(\%)\end{array}$ \\
\hline Group $\mathbf{G}_{1}$ & $10-\mathrm{W}$ & - & 2.39 & - & - & - \\
\hline \multirow{3}{*}{ Group $\mathbf{G}_{2}$} & 2-S/A/W & \multirow{3}{*}{34.47} & \multirow{3}{*}{41.29} & Cyathura carinata & 44.68 & \multirow{3}{*}{59.14} \\
\hline & $3-\mathrm{S} / \mathrm{A} / \mathrm{W}$ & & & \multirow{2}{*}{ Corophium sp. } & \multirow{2}{*}{14.46} & \\
\hline & $\begin{array}{c}4-\mathrm{A} \\
10-\mathrm{S}\end{array}$ & & & & & \\
\hline \multirow{4}{*}{ Group $\mathbf{G}_{3}$} & 5-S/A & \multirow{4}{*}{36.78} & \multirow{4}{*}{31.32} & Scolelepis squamata & 32,37 & \multirow{4}{*}{63.69} \\
\hline & 6-S/A/W & & & \multirow{3}{*}{ Alkmaria romijni } & \multirow{3}{*}{31.32} & \\
\hline & $8-\mathrm{S} / \mathrm{A} / \mathrm{W}$ & & & & & \\
\hline & 10-A & & & & & \\
\hline \multirow{4}{*}{ Group $\mathbf{G}_{4}$} & $1-\mathrm{S} / \mathrm{A} / \mathrm{W}$ & \multirow{4}{*}{39.86} & \multirow{4}{*}{25.00} & Hediste diversicolor & \multirow[t]{2}{*}{59.57} & \multirow{4}{*}{82.60} \\
\hline & 4-S/W & & & \multirow{3}{*}{ Scolelepis squamata } & & \\
\hline & $\begin{array}{c}5-W \\
7-S / A / W\end{array}$ & & & & 23.03 & \\
\hline & $9-\mathrm{S} / \mathrm{A} / \mathrm{W}$ & & & & & \\
\hline $\begin{array}{c}\text { Number of } \\
\text { Variables }\end{array}$ & \multicolumn{6}{|c|}{ BIOENV ANALYSIS-BEST VARIABLES COMBINATION } \\
\hline \multirow{3}{*}{1} & \multicolumn{2}{|r|}{0.311} & \multicolumn{2}{|c|}{0.261} & \multicolumn{2}{|c|}{0.249} \\
\hline & \multirow{2}{*}{\multicolumn{2}{|c|}{$\begin{array}{c}\text { Fine Sand } \\
(0.125-0.250 \mathrm{~mm})\end{array}$}} & \multirow{2}{*}{\multicolumn{2}{|c|}{$\begin{array}{l}\text { Organic Matter } \\
\text { (MO) }\end{array}$}} & \multirow{2}{*}{\multicolumn{2}{|c|}{$\begin{array}{c}\text { Median Sand } \\
(0.250-0.500 \mathrm{~mm})\end{array}$}} \\
\hline & & & & & & \\
\hline \multirow{3}{*}{2} & \multicolumn{2}{|r|}{0.350} & \multicolumn{2}{|c|}{0.346} & 0 & 31 \\
\hline & Fine $\mathrm{S}$ & and + Coarse Sand & Fine Sand + & rganic Matter & Median Sand - & Organic Matter \\
\hline & $(0.125$ & $0.250 / 0.500-1 \mathrm{~mm})$ & $(0.125-0.2$ & $\mathrm{mm}+\mathrm{MO})$ & $(0.250-0.50$ & $\mathrm{mm}+\mathrm{MO})$ \\
\hline & & 0.382 & & & & \\
\hline 3 & Fine $\mathrm{Sa}$ & nd + Coarse Sand + & Median Sand & Coarse Sand + & & \\
\hline 3 & & rganic Matter & Orgar & Matter & Sand + Medial & Sand + Coarse Sand \\
\hline & $(0.125-0.2$ & $50 / 0.500-1 \mathrm{~mm}+\mathrm{MO})$ & $(0.250-1$ & $\mathrm{m}+\mathrm{MO})$ & & (IIIII) \\
\hline
\end{tabular}


evenness values during all seasons, which suggested that the macrobenthic community in these areas could potentially adapt and survive more easily to new environmental conditions.

The mean abundance, diversity and evenness values found in the Minho estuary saltmarsh in this study were much lower than those reported by Sousa et al. (2008) along the Minho River mainstream gradient in 2006 (Abundance = $3716 \mathrm{ind} / \mathrm{m}^{2} ; n=28$ different species; Shannon-Wiener index $\left(\mathrm{H}^{\prime}\right)=1.36$ and Pielou evenness index $\left.\left(\mathrm{J}^{\prime}\right)=0.41\right)$, which reinforces the idea that macrobenthic community structure of these saltmarsh areas is being influenced by anthropogenic metal contamination. However, comparisons with other European estuaries have shown that the Minho estuary saltmarsh is colonized by the typical marine macrobenthos species associated with sandy sediments with low organic matter contents (Attrill et al., 1996; Rundle et al., 1998; Bruyndoncx et al., 2002; Ysebaert et al., 2002, 2003 and Sousa et al., 2008;). Normally, these marine downstream areas have low abundance and diversity values because sandier ecosystems cannot sustain rich macrobenthic communities (Vasconcelos \& Cerqueira, 2001; Sousa et al., 2008 and Costa-Dias et al., 2010).

\section{Macrozoobenthos community composition}

The cluster multivariable analyses constructed four significantly different faunal groups $\left(\mathrm{G}_{1}\right.$, $\mathrm{G}_{2}, \mathrm{G}_{3}$ and $\mathrm{G}_{4}$ ) in the saltmarsh (Table 4).

The group $G_{1}$ (winter: site 10) was established without a mean similarity or species dominance value and represents $2.39 \%$ of the total abundance of macrobenthic community. As expected, site 10 during winter showed completely unique abiotic and biotic characteristics: the sediments were dominated by the fine sand fraction and had medium organic matter content, no metal anthropogenic contamination was observed, and the site presented the lowest total abundance and diversity values and the highest evenness index.

The group $\mathrm{G}_{2}$ (summer, autumn and winter: sites 2 and 3; autumn-site 4; summer-site 10) was formed with a mean similarity of $34.47 \%$ and represented $41.29 \%$ of the total abundance; the dominant species Cyathura carinata contributed $44.68 \%$ to this cluster. Almost all of the sites of this group are located along the Coura River mainstream, with sediments dominated by gravel and very coarse sand, low organic matter contents and low metal concentrations, but all had high total abundances and low evenness indices. This cluster can be considered as the most species-rich macrobenthic group of the saltmarsh.

The group $\mathrm{G}_{3}$ (summer: sites 5, 6 and 8; autumn: sites 5, 6, 8 and 10; winter: sites 6 and 8) was formed with a mean similarity of $36.78 \%$ and represented $31.32 \%$ of the total abundance; Scolelepis squamata contributed $32.37 \%$ to the group. This group is formed by sites located in the interior areas of the saltmarsh, and their finer sediments, higher organic matter contents and some evidence of metal contamination are coupled with low macrobenthic abundances and diversities and high evenness indices.

Finally, group $\mathrm{G}_{4}$ (summer: sites 1, 4, 7, 9 and 10; autumn: sites 1, 7 and 9; winter: sites 1, 4, 5, 7 and 9) was formed with a mean similarity of $39.86 \%$ and represented $25.00 \%$ of the total abundance of the macrobenthic community; Hediste diversicolor contributed $59.57 \%$. This last cluster grouped sites with different abiotic (sediments with high reductions of finer fractions and organic matter contents from summer to autumn and winter, as well as both contaminated and uncontaminated sediments) and biotic (sites with high and low numbers of species, ShannonWiener diversity values and evenness indices) characteristics.

These cluster multivariate analyses suggested that in cases of acute contamination associated with the death of macrobenthic communities, the areas of group $G_{1}$ may suffer greater negative environmental impacts while those of groups $\mathrm{G}_{2}-$ $\mathrm{G}_{4}$ will adapt more readily to the new environmental conditions.

However, the principal component analysis (PCA) based on the biotic and abiotic data from the two most different hydrological conditions (Su: Summer and W: Winter) obtained only three clusters of sampling sites (A, B and C) (Fig. 3). This PCA explained a total of $76.07 \%$ of the data variability and showed the same positive correla- 
tions between the sampling sites with finer sediment fractions and metal concentrations. $\mathrm{PC}_{1}$ (explaining a total of $51.90 \%$ of the data variability) was positively influenced by the coarser sediment fractions and negatively impacted by the very fine sand, silt and clay fractions, organic matter contents and metal concentrations. $\mathrm{PC}_{2}$ explained only $24.17 \%$ of the data variability and was associated with the biotic characteristics of the macrobenthic communities.

Furthermore, the BIO-ENV analysis (Spearman Coefficient) used to study the influence of the abiotic variables in the biotic ecosystems revealed that the texture of the sediments was the most important variable to the macrobenthic community structure, particularly the fine sand fraction $(\rho=0.311)$ and organic matter contents ( $\rho=0.261)$ (Table 4). Even when BIO-ENV combined more than one variable, the metal concentrations in the sediments were never shown as a significant "best variable combination" (Table 4).

The comparison of the 4 faunal groups $\left(G_{1}\right.$, $\mathrm{G}_{2}, \mathrm{G}_{3}$ and $\mathrm{G}_{4}$ ) formed by the "cluster multivariate analysis" and the 3 abiotic groups (A, B and $\mathrm{C}$ ) formed by the PCA confirmed that the group distributions were not the same, although some sites remained associated. This result sug- gested that macrobenthic community structure of the Minho estuary saltmarsh was not directly influenced by metals. The presence of high metal concentrations might be considered as a simple disturbing factor. Although the saltmarsh showed evidence of anthropogenic contamination by metals, the texture of the sediments was the main structuring factor of the area's macrobenthic community.

\section{CONCLUSIONS}

The texture and organic matter contents of the sediments showed high spatial and seasonal variations across the Minho estuary saltmarsh for the three sampling dates, which demonstrated their complex sedimentary dynamics. The metal concentrations of the sediments also showed significant spatial and seasonal variations $(p<0.05)$, which coincided with the variations in texture and organic matter contents between sampling sites and seasons. However, the metal concentrations in the sediments were not exclusively influenced by natural sources, showing evidence of anthropogenic contamination in the saltmarsh's interior areas during

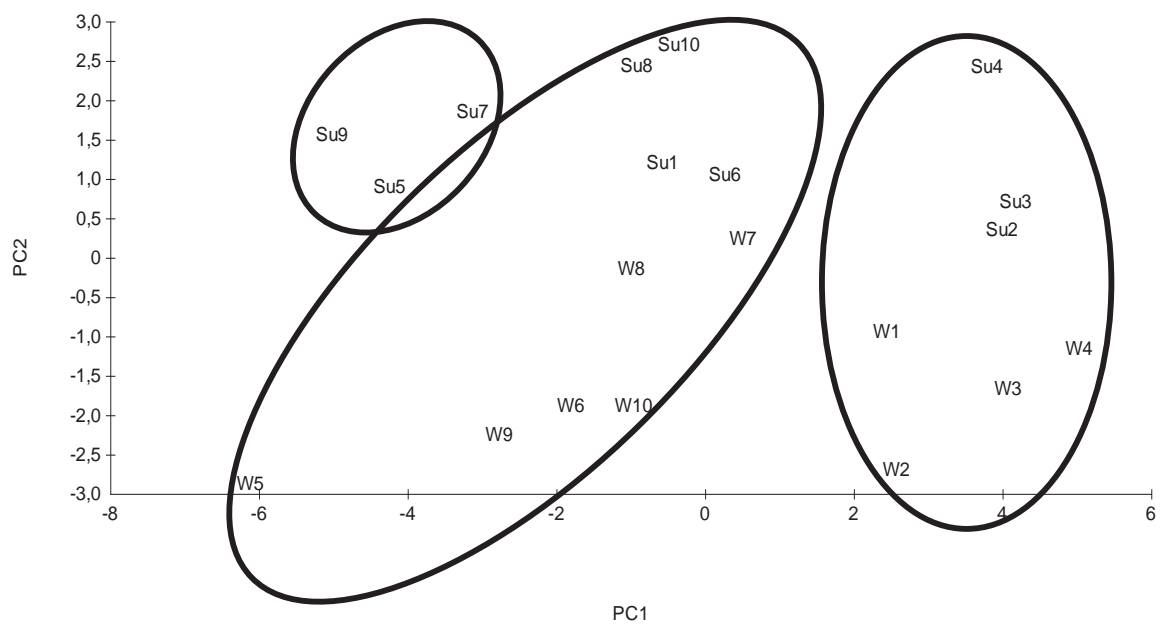

Figure 3. Principal Component Analysis (PCA) of the biotic and abiotic factors of the sediments of the Minho estuary saltmarsh during the two extreme hydrological conditions: Summer $(\mathrm{Su})$ and Winter $(\mathrm{W})$. Análisis de Componentes Principales (PCA) de los factores bióticos y abióticos de los sedimentos del estuario del río Miño, durante dos condiciones hidráulicas extremas: verano (Su) e invierno $(W)$. 
summer (sites 5 and 7) and winter (site 5). The macrobenthic community structure of this saltmarsh was composed of a total of 37 taxa. The mean annual abundance was $1530 \mathrm{ind} / \mathrm{m}^{2}$, and the most abundant species were Cyathura carinata, Scolelepis squamata and Hediste diversicolor. However, these species showed no consistent variation across the saltmarsh, and their abundances and diversities displayed high spatial and seasonal variations directly influenced by the natural characteristics of the sediments and the environmental conditions typical of each season. Although the saltmarsh showed evidence of anthropogenic contamination by metals, the main structuring factor of its macrobenthic community was the texture of the sediments. The evidence of anthropogenic contamination by metals should be further studied and included in periodic ecological monitoring and remediation programs for the Minho estuary saltmarsh. Additionally, it must be stressed that these preliminary results should be strengthened with more complete monitoring programs and comparisons with macrobenthic community structures from different national and international saltmarshes.

\section{REFERENCES}

ATTRILL, M. J., S. D. RUNDLE \& R. M. THOMAS. 1996. The influence of drought-induced low freshwater flow on an upper-estuarine macroinvertebrate community. Water Research, 30: 261-268.

ALVES, A. M. 1996. Causas e processos da dinâmica sedimentar na evolução actual do litoral do Alto Minho. PhD Thesis in Sciences, Department of Earth Sciences, University of Minho.

ALVES, E. 2000. Plano de Bacia Hidrográfica do rio Minho: Análise e Diagnóstico da Situação Actual. Anexo 11-Situações Hidrológicas ExtremasCheias. Relatory N. ${ }^{\circ} 53 / 00-N H E$, Lisbon, LNEC, 25-29.APHA. 1998. Standard Methods for the Examination of Water and Wastewater. Section: Introdution; Method: 1030C-Data Quality. 20th edition. American Public Health Association, Washington, DC.

ASENSIO, A. I. \& M. M. J. GÓMEZ. 1984. Oceanografía física: Factores que condicionan la diná- mica litoral en la Ría del Eo. Issue from Galician Studies Seminary, 79-90.

BRUYNDONCX, L, K. JORDAENS, T. YSEBAERT, P. MEIRE \& T. BACKELJAU. 2002. Molluscan diversity in tidal marshes along the Scheldt estuary (The Netherlands, Belgium). Hydrobiologia, 474: 189-196.

CANFIELD, T. J., N. E. KEMBLE, W. G. BRUMNAUGH, F. J. DWYER, J. F. INGERSOLL \& C. G. FAIRCHILD. 1994. Use of benthic invertebrates community structure and the Sediment Quality Triad to evaluate metal-contaminated sediment in the upper Clark Fork River, Montana. Environmental Toxicology and Chemistry, 13: 1999-2012.

CHAPMAN, P. M. \& F. WANG. 2001. Assesing sediment contamination in estuaries. Environmental Toxicology and Chemistry, 20: 3-22.

CLARKE, K. \& R. GORLEY. 2001. PRIMER v5 User manual/Tutorial. Plymouth, PRIMER-E Ltd.

CLARKE, K. R. \& R. M. WARWICK. 1994. Changes in marine communities: an approach to statistical analysis and interpretation. Plymouth, Natural Environmental Research Council.

COSTA-DIAS, S., V. FREITAS, R. SOUSA \& C. ANTUNES. 2010. Factors influencing epibenthic assemblages in the Minho Estuary (NW Iberian Peninsula). Marine pollution bulletin, 61: 240-246.

DAY, J. W., C. A. S. HALL, W. M. KEMP \& A. YÁNEZ-ARANCIBIA. 1989. Estuarine Ecology. New York, Wiley - Interscience Publication.

DAUVIN, J. C. 2007. Paradox of estuarine quality: benthic indicators and indices, consensus or debate for the future. Marine Pollution Bulletin, 55: 271281.DIEZ, J. 1980. Introducción al estudio geomorfológico y de los procesos litorales en la Ría de Foz. Issue from Galician Public Building Relatory, 941-952.

ELLIOTT, M. \& V. M. QUINTINO. 2007. The Estuarine Quality Paradox, Environmental Homeostasis and the difficulty of detecting anthropogenic stress in naturally stressed areas. Marine Pollution Bulletin, 54: 640-645.

EPA-U.S. ENVIRONMENTAL PROTECTION AGENCY. 1994. Method 3051-Microwave assisted acid digestion of sediments, sludges and soils. Test Methods for Evaluating Solid Waste, SW-846, 3rd ed., Office of Solid Waste and Emergency Response of Washington, D.C. 
FARINHA, J. C. \& A. TRINDADE. 1994. Contribuição para o Inventário e Caracterização de Zonas Húmidas em Portugal Continental. Portuguese Institute of Nature Conservation (ICN)/ MedWet Publication.

GAMBOA, M. 1999. Plano de Bacia Hidrográfica do rio Minho: Análise e Diagnóstico da Situação Actual. Anexo 1 - Análise Biofísica, Parte IIIClima. Relatory N. ${ }^{\circ}$ 318/99-GHi, Lisbon, LNEC.

GASTON, G. R. \& J. C. NASCI. 1998. Trophic structure of macrobenthic communities in the Calcasieu Estuary, Louisiana. Estuaries, 3: 201-211.

LAMBSHEAD, P. J. D., H. M. PLATT \& K. M. SHAW. 1983. The detection of differences among assemblages of marine benthic species based on an assessment of dominance and diversity. Journal of Natural History, 17: 859-874.

LANA, P. C. 1994. Organismos bénticos e actividades de monitoramento. Issue In: Biological Oceanography. Oceanic and Coastal Environmental Diagnostic from South and Southeast regions of Brazil, PETROBRÁS-FUNDESPA: 10-21.

MIL-HOMENS, M., A. M. COSTA, S. FONSECA, M. A. TRANCOSO, C. LOPES, R. SERRANO \& R. SOUSA. 2013a. Characterization of heavymetal contamination in surface sediments of the Minho river estuary by way of factor analysis. Archives of environmental contamination and toxicology, 64: 617-631.

MIL-HOMENS, M., A. M. COSTA, S. FONSECA, M.A. TRANCOSO, C. LOPES, R. SERRANO \& R. SOUSA. 2013b. Natural heavy metal and metalloid concentrations in sediments of the Minho River estuary (Portugal): baseline values for environmental studies. Environmental monitoring and assessment, 185: 5937-5950.

MORA, J. 1980. Poblaciones bentônicas de la Ría de Arosa. PhD Thesis, Biology Faculty, University of Santiago de Compostela.

MUCHA, A. P., M. T. S. D. VASCONCELOS \& A. A. BORDALO. 2003. Macrobenthic community in the Douro estuary: relations with trace metals and natural sediments characteristics. Environmental Pollution, 121: 169-180.

PEARSON, T. H. \& R. ROSENBERG. 1978. Macrobenthic succession in relation to organic enrichment and pollution of marine environment. Oceanography and Marine Biology: An Annual Review, 16: 229-311.

RAKOCINSKI, C. F., S. S. BROWN, G. R. GASTON, R. W. HEARD, W. W. WALKER \& J. K.
SUMMERS. 1997. Macrobenthic responses to natural and contaminant-related gradients in northern Gulf of Mexico estuaries. Ecological Applications, 7: 1278-1298.

REIS, P. A., J. C. ANTUNES \& C. M. R. ALMEIDA. 2009. Metal levels in sediments from the Minho estuary salt marsh: a metal clean area? Environmental Monitoring and Assessment, 159: 191-205.

RUNDLE, S. D, M. J. ATTRILL \& A. ARSHAD. 1998. Seasonality in macroinvertebrates community composition across a neglected ecological boundary, the freshwater-estuarine transition zone. Aquatic Ecology, 32: 211-216.

SCHIFF, K. C. \& S. B. WEISBERG. 1999. Iron as a reference element for determining trace metal enrichment in southern California coastal shelf sediments. Marine Environmental Research, 48: 161176.

SOUSA, R., S. DIAS, V. FREITAS \& C. ANTUNES. 2008. Subtidal macrozoobenthic assemblages along the River Minho estuarine gradient (northwest Iberian Peninsula. Aquatic Conservation: Marine and Freshwater Ecosystems, 18: 10631077.

SOUSA, C. M., N. VAZ, I. ALVAREZ \& J. M. DIAS. 2013. Effect of Minho estuarine plume on Rias Baixas: numerical modeling approach. Journal of Coastal Research, Special Issue 65: 2059-2065.

TEAL, J. M. 1986. The ecology of regularly flooded salt marshes of New England: A community profile. Fish and Wildlife Service, Division of Biological Services, Washington. D. C. Biology Report, 85: 77.

VALE, C., F. M. CATARINO, C. CORTESÃO \& M. I. CAÇADOR. 1990. Presence of metal-rich rhizoconcretions on the roots of Spartina maritima from the salt marshes of the Tagus estuary, Portugal. Science of Total Environment, 98: 617-626.

VASCONCELOS, V., \& M. CERQUEIRA. 2001. Phytoplankton community of river Minho (International Section). Limnetica, 20: 135-141.

VELINSKY, D. J., T. L. WADE, C. E. SCHLEKAT, B. L. MCGEE \& B. J. PRESLEY. 1994. Tidal river sediments in the Washington D. C. Area. I. Distribution and sources of trace metals. Estuaries, 17: 305-320.

WARWICK, R. M. 1986. A new method for detecting pollution effects on marine macrobenthic communties. Marine Biology, 92: 557-562.

WEISBERG, S. B., J. A. RANASINGUE, D. M. DAUER, L. C. SCAFFNER, R. J. DIAZ \& J. B. 
FRITHSEN. 1997. An estuarine benthic index of biotic integrity (B-IBI) for Chesapeake Bay. Estuaries, 20: 149-158.

YSEBAERT, T., P. MEIRE, P. M. J. HERMAN \& H.
VERBEEK. 2002. Macrobenthic species response surfaces along estuarine gradients: prediction by logistic regression. Marine Ecology Progress Series, 225: 79-95. 